\title{
Studies on Separation of Macerals from Coal by Froth Flotation
}

\author{
Saroj Kumar Sahoo ${ }^{1, ~}$, Nikkam Suresh ${ }^{1}$, Atul Kumar Varma ${ }^{2}$ \\ ${ }^{1}$ Department of Fuel and Mineral Engineering, Indian Institute of Technology (Indian School of Mines), Dhanbad, India \\ ${ }^{2}$ Department of Applied Geology, Indian Institute of Technology (Indian School of Mines), Dhanbad, India
}

\section{Email address:}

sarojsahoo.19@gmail.com (S. K. Sahoo)

${ }^{*}$ Corresponding author

\section{To cite this article:}

Saroj Kumar Sahoo, Nikkam Suresh, Atul Kumar Varma. Studies on Separation of Macerals from Coal by Froth Flotation. Journal of Energy and Natural Resources. Vol. 6, No. 3, 2017, pp. 38-44. doi: 10.11648/j.jenr.20170603.12

Received: July 19, 2017; Accepted: August 1, 2017; Published: August 17, 2017

\begin{abstract}
In the past coal maceral separation have been carried out based on density difference e.g., sink-float analysis, density gradient centrifugation (DGC) techniques etc. These approaches are of limited success. Froth flotation is a physicochemical process separating particles on the basis of difference in surface properties in a vessel consisting of two distinct zones viz., pulp and froth zones. Rate of floatability of individual size range particles varies with their ash percent and the maceral content present. Therefore, the flotation rate constant eventually becomes a function of maceral percentage of a coal particle. In the present paper, an attempt has been made by performing size-wise flotation tests using a sub-bituminous rank coal and flotation kinetics have been established based on maceral percentage reporting to concentrate at different time intervals of flotation. These results have been related to the kinetic behaviour of the process.
\end{abstract}

Keywords: Coal Flotation, Flotation Kinetics, Macerals

\section{Introduction}

Coal macerals can be defined as the microscopically recognizable organic constituents having no definite crystal structure and chemical composition. These macerals are generally classified into three major maceral groups such as vitrinite, liptinite and inertinite. Each group represents the macerals having similar properties in a coal of specific rank [1]. Several beneficiation techniques were adopted for the concentration of macerals such as froth flotation [2-5], magnetic separation [6] and electrostatic separation [7] etc. Except froth flotation technique, none of the other techniques gained any acceptance due to techno-economic factors. Some success was also achieved by taking account the gravimetric difference of macerals by using centrifugation technique [8]. Froth flotation is the physico-chemical process consists of three phases such as solid, water and air phases. It consists of two different zones such as pulp zone and froth zone. In pulp zone, mineral particles attached to the bubbles and transform to the froth zone. Froth recovery plays an important role in froth phase because it determines the recovery of valuable minerals. Froth recovery is mainly affected by bubble coalescence and water drainage [9]. Froth zone is a very complex zone and affected by multiple factors such as solid concentration, particle shape, size and hydrophobicity. Froth flotation is the process for fine coal beneficiation, since it depends upon the surface properties of coal [10]. Arnold and Aplan measured contact angles of several coal samples to quantify the hydrophobicity of individual coal macerals. It was found that the order hydrophobicity of the coal macerals was liptinite $>$ vitrinite $>$ inertinite and that these macerals have typical ranges of contact angles of $90-130^{\circ}, 60-70^{\circ}$ and $25-40^{\circ}$ respectively [11]. In another study macerals are arranged with the rate of flotation such as liptinite $>$ vitrinite $>$ inertinite, with a typical value of $0.118 \mathrm{sec}^{-1}$, $0.113 \mathrm{sec}^{-1}$ and $0.112 \mathrm{sec}^{-1}$ respectively [12]. In addition, they reported a number of studies that examined macerals or lithotype portioning, generally without consideration of the macerals association [13]. Wang et al. examined the floatability of coal macerals of Shenfu coals and tried to change it by microwave irradiation. They found an increase in the difference in the surface wettability of Shenfu fusain and Shenfu vitrain and subsequently increase in the 
enrichment of inertinite and vitrinite [14]. R. Q. Honaker, separated the macerals by using column flotation technique. In this study, they take the coal sample having size $-50 \mathrm{~mm}$ collected from Illinois no-6 seam having ash, sulfur, mineral matter, vitrinite, liptinite, inertinite, are $8.3 \%, 1.1 \%, 9.50 \%$, $79.10 \%, 3.90 \%$, and $7.50 \%$ respectively. The laboratory column flotation was used for beneficiation [15]. Sink-float technique and centrifugation technique was carried out of the flotation feed, concentrates and tailing samples and the flotation rate kinetics $(\mathrm{k})$ for the three measures groups were calculated [2]. Hardgrove grindability index (HGI) is most directly related to the coal maceral composition but it also depends on the rank of the coal. Several researchers have been studied relationship between grindability and coal petrology. They found that, as liptinite concentrates of coal increase, the HGI value decreased and it shows the direct relationship with the vitrinite percent. Hower and wild developed a strong correlation between an increase in liptinite content and decrease in HGI for coals of narrow vitrinite reflectance ranges [16]. In this paper, an attempt has been made by performing size-wise flotation test using subbituminous rank of coal and flotation kinetics have been established based on material percentage reporting at different time intervals of flotation. Therefore, the flotation rate constant eventually a function of maceral percentage of a coal particles. The coal samples are taken from Jharkhand colliery, India, with the objective of determining possibilities of the separation of maceral groups in different size fractions of $-500+150,-150+75,-75+36,-36+25$ and -25 microns, and flotation rate constant is studied with size-fraction.

\section{Experimental}

\subsection{Sample Preparation, Screening and Group Maceral Analysis}

The coal samples were taken from Jharkhand colliery, India, and -500micron size fraction was separated and used for further studies. The -500 micron fraction of coal samples is wet screened at $-500+150,-150+75,-75+40,-40+25$ and 25 microns. As it can be seen that most of the coal fractions are distributed among the coarser size fraction $(-500+150$, $150+75)$ [Table 1]. The sample retained on each fraction was subjected to ash analysis according to ASTM D3174-73 standard method. Subsequently 15 sub-samples were prepared and used for the preparation of the polished section as per ICCP Standard method. The maceral group analysis i.e. the assay of vitrinite, inertinite and liptinite was performed using microscopic studies, according to the ISO 7404-3 standard method. The proximate and petrographic analysis of sample is shown in Table 2. From proximate analysis, it is clear that the coal used is a high ash coal.

\subsection{Flotation Studies}

Flotation test was conducted in a 6-litter capacity of laboratory batch flotation cell having facilities for varying the rpm, the scraper speed and the impeller height. A pictorial view of machine used is shown in Figure 1. Size-wise flotation was carried out and time -wise froth was collected. Flotation recovery and time value are plotted to determine the rate constant in each time duration and the different size fraction are plotted with the rate constants. Time-wise ash analysis was performed. The experiments having variable parameters are pulp density, reagent dosages and fixed parameters are rpm, impeller height, and air flow-rate. The reagents were used as diesel oil as collector, pine oil as frother. The pulp was conditioned for 120 second before adding any collector and frother dosages. After adding the collector conditioning time was 60 second and frother conditioning time was 30 second. The air valve, the scraper switch and water flow rate lock is open at a time. The water flowrate maintains the pulp level of the cell. Pulp was agitated with a fixed RPM of 1000. All experiments were conducted at a natural PH of around 8. Dhanbad tap water was used in all experiment. Both, time-wise floated (concentrate) fractions and non-floated (tailings) fractions were dried in an oven at a fixed temperature of $60^{\circ} \mathrm{C}$, then weighted to calculate the yield. Froth fractions were collected at cumulative time such as $5,15,30,60$, and 90 second.

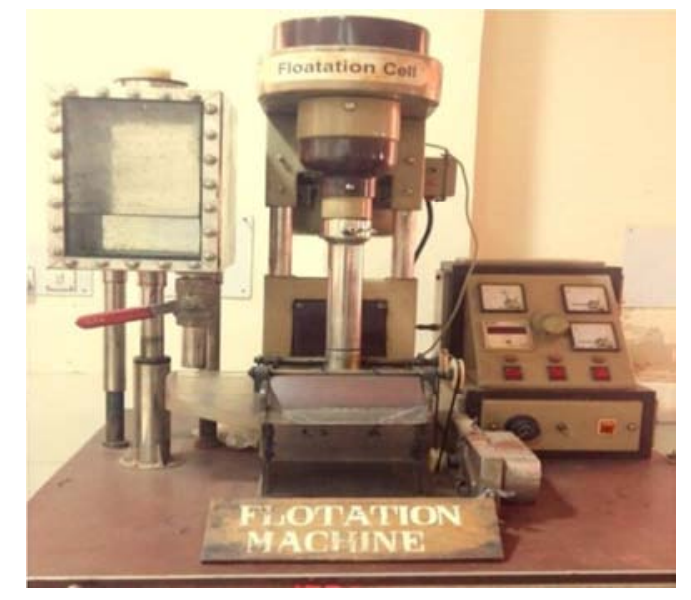

Figure 1. Scheme of Laboratory flotation cell.

\subsection{Block Preparation}

The sample obtained at each size and time-wise froth fraction were mounted in different blocks for petrographic analysis. The procedure adopted for the preparation of polished sections of coal samples is briefly explained below:

(1) Required quantity of sample was taken into a greasecoated mounting thump.

(2) About 1:2 ratios of hardener and epoxy resin of $\mathrm{M} / \mathrm{s}$ Buehler make was poured into the thump up to half of the volume.

(3) After thorough mixing the mixture of sample and resinhardener, the remaining portion of the thump was filled with diluted mixture of resin-hardener and allowed it for complete solidification.

(4) Specimen was removed from the thump, labelled and then subjected for grinding and polishing as per the ICCP standard method [17]. 


\subsection{Petrographic Studies}

The coal sample of $-0.5 \mathrm{~mm}$ size was used to prepare pellets and studied under reflected light with a "LEICA DM2700P" microscope with an oil immersion lens and fluorescence attachment, setup shown in Figure 2 following standard procedure [17] at Coal Geology and Organic Petrology Laboratory, Department of Applied Geology, Indian School of Mines, Dhanbad, India. Macerals were identified following ICCP classification of macerals [18-19]. The polished section $(2 \mathrm{~cm} \times 2 \mathrm{~cm} \times 2 \mathrm{~cm}$ mould $)$ of feed coal particles, flotation concentrates, and flotation tailings were prepared and were studied with the reflected light microscope. Around 400-500 particles were counted for this study in each case. Samples were studied under 200x and 500x magnification. In this study, the group macerals were counted based on the organic only basis, i.e. vitrinite + liptinite + inertinite $=100 \%$.

\section{Results and Discussion}

\subsection{Characterization of Feed and Different Size Fractions}

Size-wise distribution of coal fines and the corresponding ash content is shown in Figure 3. It is clear from the figure that the distribution of coal is more in first two size fraction. Vitrinite group maceral is dominant in feed coal sample followed by liptinite group maceral. Within the vitrinite group collotelinite is the predominantly noticeable maceral.
Vitrinite is noticed more in first size fraction. As size decreases the mineral matter percent and the pyrite percent increases. The presence of trimacerite (vitrinite + liptinite + inertinite) particles were very common in medium size fraction. As the size of the sample decreases the vitrinite percent increases and the liptinite content decreases, which is shown below by Table 3 and Figure 4 .

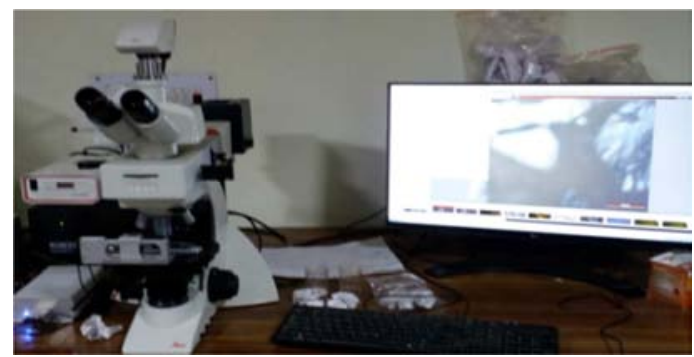

Figure 2. Petrographic set-up attached with an oil immersion lens connected to computer.

Table 1. Size and Size-wise ash distribution of feed coal sample.

\begin{tabular}{llllll}
\hline size $(\boldsymbol{\mu})$ & wt. (g) & wt.\% & ash\% & $\begin{array}{l}\text { cum wt.\% } \\
\text { retained }\end{array}$ & $\begin{array}{l}\text { cum wt.\% } \\
\text { passing }\end{array}$ \\
\hline$-500+150$ & 1026 & 55.76 & 42.14 & 55.76 & 44.24 \\
$-150+75$ & 285 & 15.49 & 41.14 & 71.25 & 28.75 \\
$-75+40$ & 165 & 8.97 & 38.85 & 80.22 & 19.78 \\
$-40+25$ & 84 & 4.57 & 41.02 & 84.78 & 15.22 \\
$-25+0$ & 280 & 15.22 & 44.81 & 100.00 & 0.00 \\
\hline
\end{tabular}

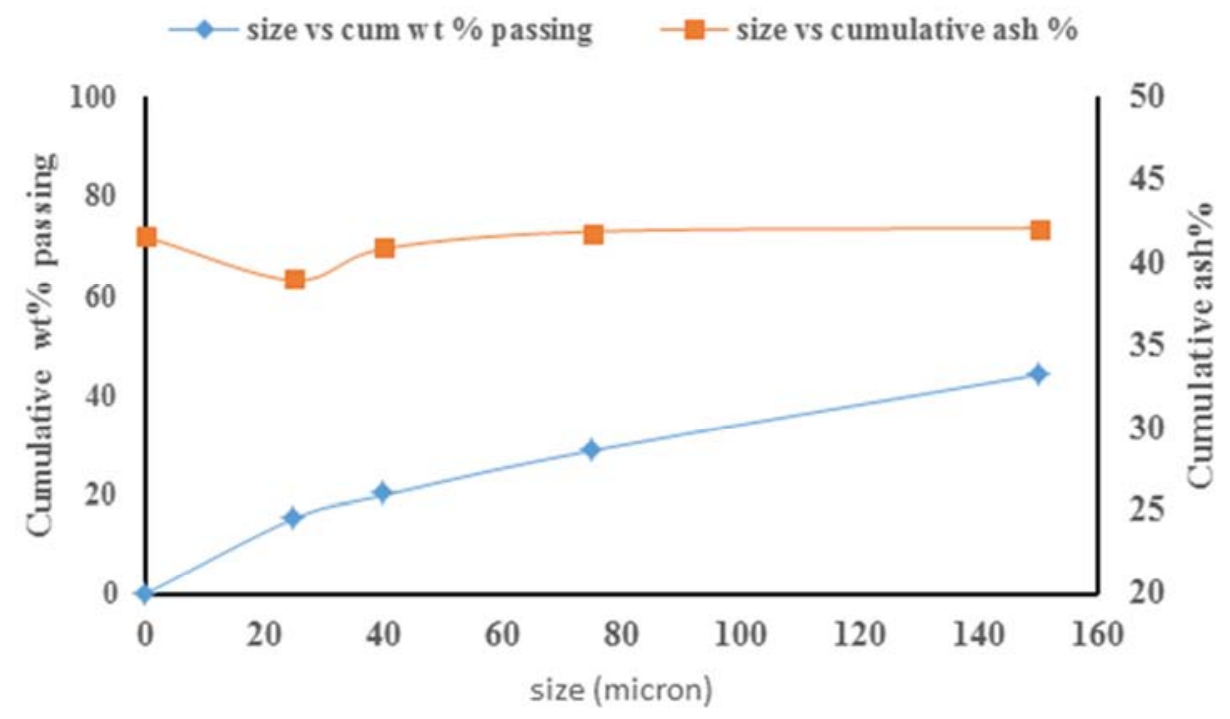

Figure 3. Distribution of coal fines and ash in various size fractions.

Table 2. Proximate and petrographic analysis of feed coal fines.

\begin{tabular}{llll}
\hline Proximate analysis & Weight \% & Petrographic analysis & Volume \% \\
\hline Moisture & 0.50 & Vitrinite & 73.28 \\
Volatile Matter & 28.72 & Liptinite & 15.74 \\
Ash & 42.14 & Inertinite & 10.25 \\
Fixed Carbon & 28.65 & Mineral Matter & 0.68 \\
& & Pyrite & 0 \\
\hline
\end{tabular}


Table 3. Petrographic composition at different size fraction of coal sample.

\begin{tabular}{llll}
\hline Size $(\boldsymbol{\mu})$ & vitrinite & liptinite & inertinite \\
\hline$-500+150$ & 73.79 & 15.86 & 10.34 \\
$-150+75$ & 78.23 & 8.00 & 20.00 \\
$-75+40$ & 81.51 & 1.26 & 13.03 \\
\hline
\end{tabular}

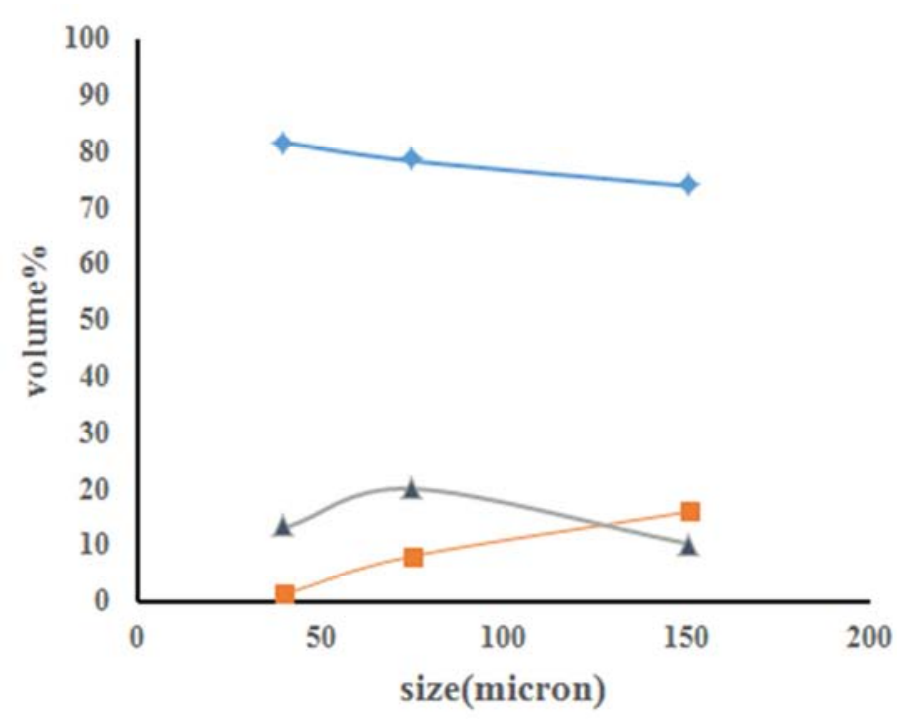

Figure 4. Variation of vitrinite, inertinite, and liptinite w. r. t size fraction.

\subsection{Characterization of Maceral at Different Time of Froth Concentrate}

Maceral distribution at different time-wise froth concentrate was computed with conventional point counter procedure and the same has been represented in terms volume percentage in Figure 5 and Figure 6 . It can be observed from the figure that about $80 \%$ of vitrinite group maceral is floated in first 10 second. Collotelinite is the dominating maceral in vitrinite group. As proceeding to higher time fraction percentage of vitrinite group maceral decreases while inertinite group maceral increases only deviation shows at 60 second. Image microphotographs observed at different time duration of froth are shown in Figure 6. Table 4 and Table 5 shows as time of froth collection increases the mineral matter percent and pyrite percent increases of both size fraction. Complete liberation of inertinite group maceral i.e. semi-fusinite and fusinite and liptinite group maceral i.e. sporinite along with small and wide band of cutinite has found at different time duration of froth fraction is shown in concentrate. Micrinite and macrinite maceral of inertinite group found widely at different froth fraction.

Table 4. Shows the variation of petrographic components with respect to time of size $-500+150 \mu$.

\begin{tabular}{|c|c|c|c|c|c|c|c|}
\hline Time & $\mathbf{v}$ & I & $\mathbf{i}$ & $\mathbf{m m}$ & pyrite & $\operatorname{cum} \operatorname{ash} \%$ & $\operatorname{ash} \%$ \\
\hline 0 & 0 & 0 & 0 & 0 & 0 & 0.00 & 0.00 \\
\hline 5 & 77.02 & 12.3 & 8.69 & 2.05 & 0 & 32.77 & 32.77 \\
\hline 15 & 73.47 & 6.94 & 14.33 & 4.78 & 0.43 & 33.59 & 34.80 \\
\hline 30 & 63.86 & 12.89 & 14.83 & 7.09 & 1.29 & 33.72 & 34.12 \\
\hline 60 & 72.21 & 7.4 & 11.1 & 8.34 & 1.92 & 35.70 & 42.61 \\
\hline 90 & 48.92 & 15.94 & 13.81 & 18.08 & 3.19 & 36.44 & 50.11 \\
\hline tailings & 47.81 & 5.31 & 8.49 & 25.53 & 12.76 & 42.01 & 64.52 \\
\hline
\end{tabular}

Table 5. Shows the variation of petrographic components with respect to time of size $-74+36 \mu$.

\begin{tabular}{|c|c|c|c|c|c|c|c|}
\hline Time & $\mathbf{v}$ & I & $\mathbf{i}$ & $\mathbf{m m}$ & pyrite & $\operatorname{ash} \%$ & $\operatorname{cum} \operatorname{ash} \%$ \\
\hline 0 & 0 & 0 & 0 & 0 & 0 & 0 & 0.00 \\
\hline 5 & 71.14 & 1.97 & 17.38 & 7.9 & 1.5 & 34.02 & 34.02 \\
\hline 15 & 61.5 & 0.34 & 25.76 & 9.62 & 2.96 & 32.88 & 33.52 \\
\hline 30 & 60.01 & 4 & 32.01 & 0 & 4 & 43.19 & 34.81 \\
\hline 60 & 78.17 & 7.27 & 10.89 & 3.63 & 0 & 49.67 & 35.70 \\
\hline 90 & 48 & 12 & 16 & 20 & 4 & 41.61 & 35.81 \\
\hline tailings & 78.87 & 8.45 & 8.43 & 4.22 & 0 & 57.95 & 41.72 \\
\hline
\end{tabular}




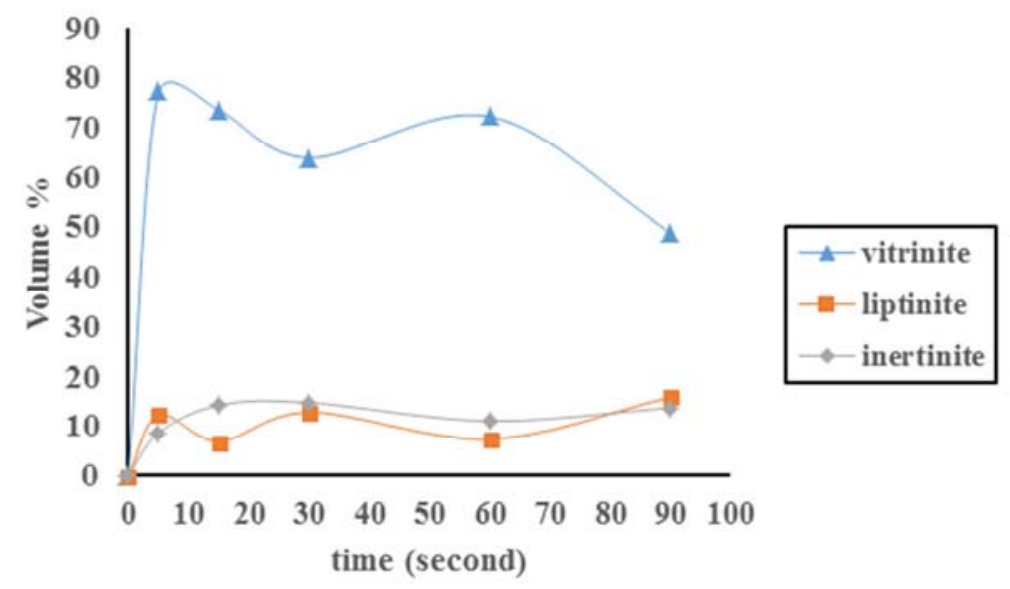

Figure 5. Shows time-wise variation of macerals in froth of size $-500+150 \mu$.

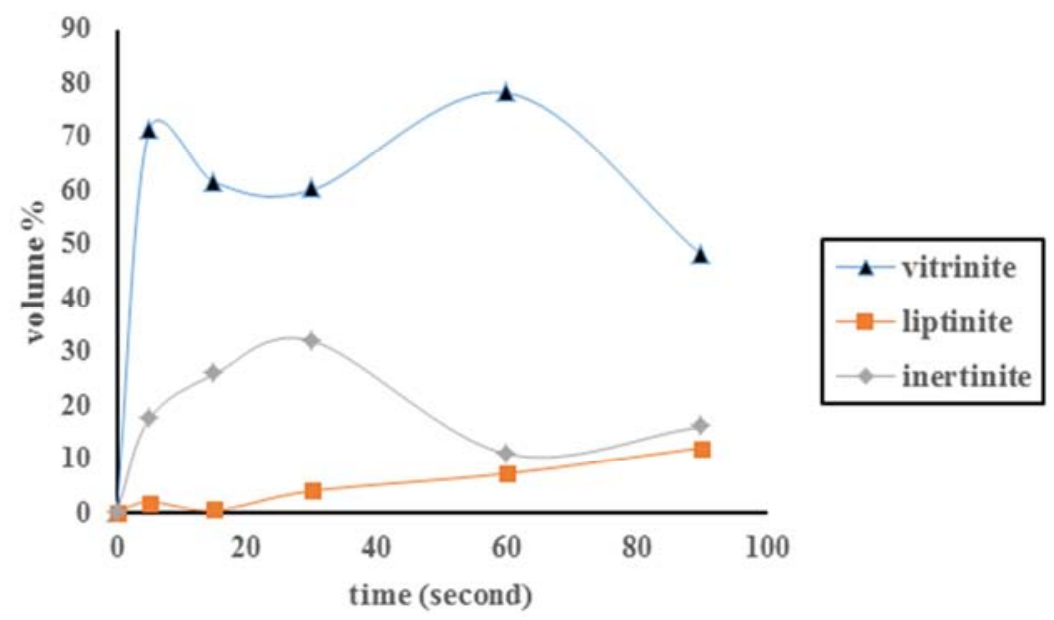

Figure 6. Shows time-wise variation of maceral in froth of size $-74+36 \mu$.

\subsection{Component Partitioning and Rate Constant}

Figure 7. is a plot of the cumulative component recovery versus flotation time for the $-500+150 \mu$ size. The figure shows that for this size fraction, the liberated vitrinite component has the highest flotation rate and ultimate recovery. This is followed by inertinite rich component, which has less rate of flotation an ultimate recovery than vitrinite. The component having lowest rate of flotation and ultimate recovery is the liptinite.

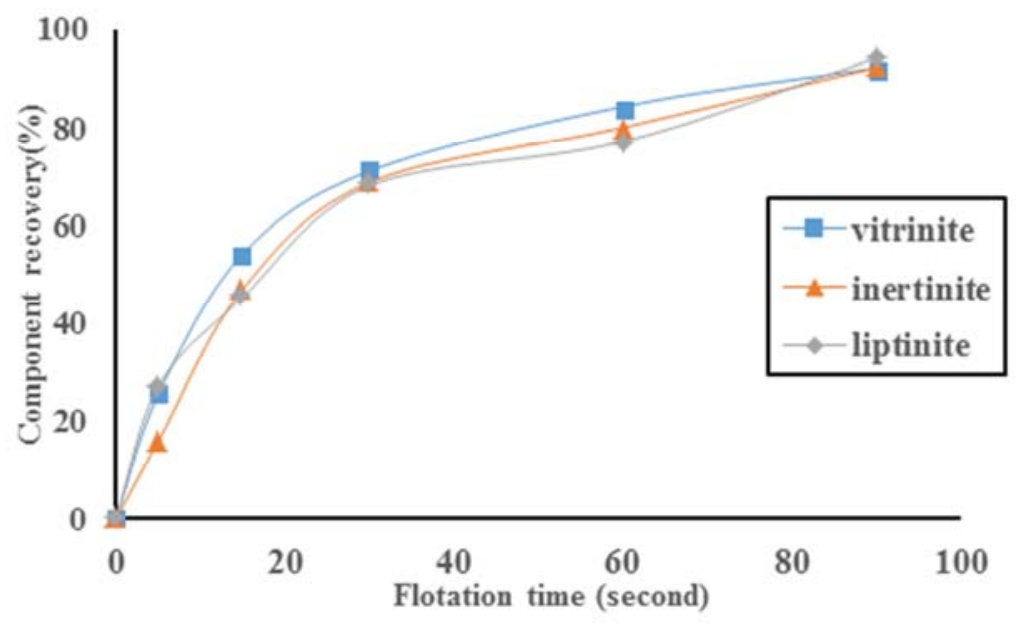

Figure 7. Flotation kinetics of the different macerals of the coal for the $-500+150 \mu$ size fraction. 
Figure 8 . shows the cumulative component recovery as a function of flotation time for the intermediate size fraction of $-74+36 \mu$. In this size fraction, the rate of recovery and ultimate recovery of inertinite is higher than the vitrinite component. Unlike the coarse size fraction, they are only slightly higher than those of inertinite and vitrinite component. The rate of recovery and ultimate recovery of the liptinite component are significantly lower than vitrinite and inertinite rich component. For this intermediate size fraction, significantly higher amount of vitrinite is recovered than the coarse $-500+150 \mu$ size.

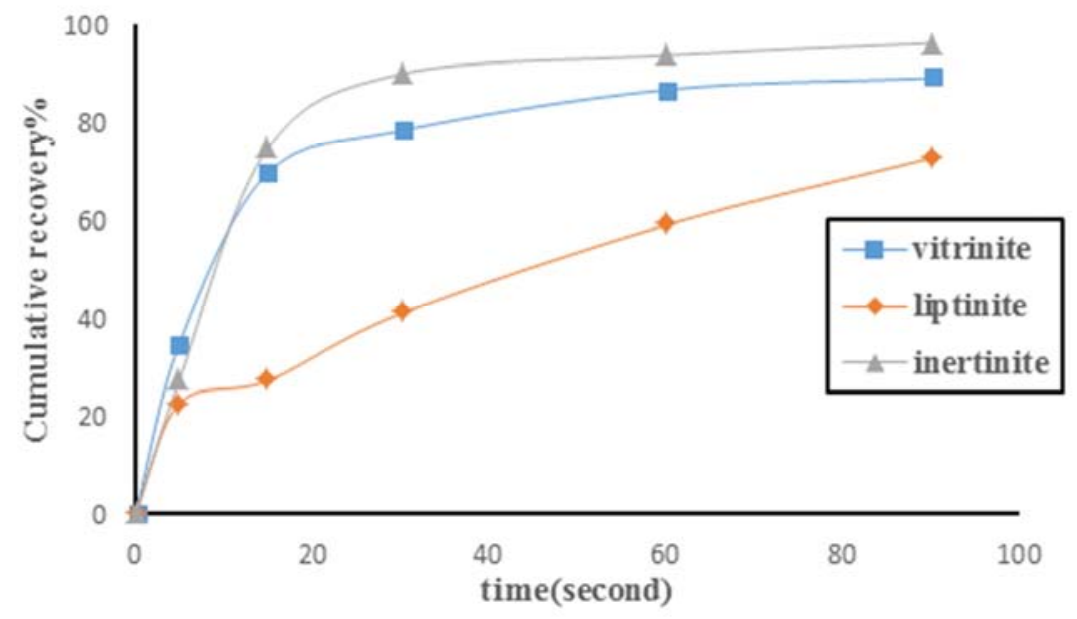

Figure 8. Flotation kinetics of different macerals of the coal for the $-74+36 \mu$ size fraction.

The flotation rate constant and the ultimate recoveries for the different macerals of the two-size fraction were extracted from the kinetic data by fitting the experimental data to the first order flotation model, using non-linear least square technique and are presented in Table 6.

Table 6. Shows kinetic parameter of macerals.

\begin{tabular}{llll}
\hline Size fraction & Maceral & Flotation rate constant (k) & Ultimate recovery $\left(\mathbf{R}_{\infty}\right)$ \\
\hline$-500+150 \mu$ & Vitrinite & 0.046 & 95.6 \\
& Inertinite & 0.043 & 95.0 \\
& Liptinite & 0.042 & 92.3 \\
& Total & 0.046 & 85.0 \\
$-74+36 \mu$ & Vitrinite & 0.068 & 90.0 \\
& Inertinite & 0.083 & 98.0 \\
& Liptinite & 0.026 & 75.0 \\
\hline
\end{tabular}

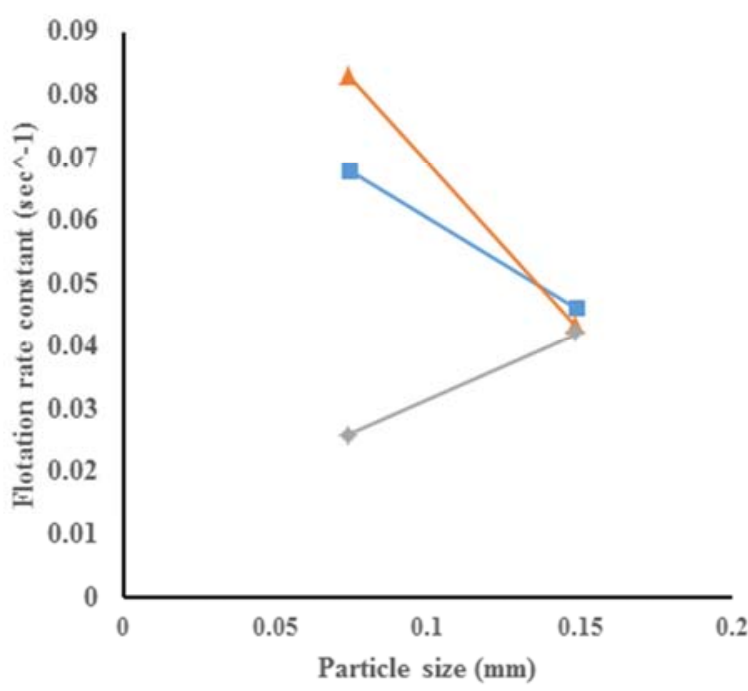

Figure 9. Flotation rate constant versus particle size for coal maceral component. 
Figure 9 indicates as particle size increases, the flotation rate of vitrinite and inertinite decreases in a constant manner, but deviation takes place in case of liptinite maceral.

\section{Conclusion}

Following are the conclusions are drawn from the above study conducted.

(i) As the particle size decreases the rate constant of vitrinite and inertinite component decrease.

(ii) For coarser size fraction liberated vitrinite component have highest flotation rate constant and ultimate recovery than inertinite component.

(iii)In case of fine-size fraction the rate of recovery and ultimate recovery of inertinite component has the highest value than the vitrinite component.

(iv)Finally, it can be concluded that significant amount of vitrinite component is recovered from $-500+150 \mu$ size fraction.

\section{References}

[1] Jiménez, A., Iglesias, M. J., Laggoun-Défarge, F., \& SuarezRuiz, I. (1998). Study of physical and chemical properties of vitrinites. Inferences on depositional and coalification controls. Chemical Geology, 150(3), 197-221.

[2] Yerriswamy, P., Modi, O. P., Rao, K. K., \& Rao, T. C. (2000). Characterization of Macerals in Coal Fines using Image Analysis Technique.

[3] Honaker, R. Q., Mohanty, M. K., \& Crelling, J. C. (1996). Coal maceral separation using column flotation. Minerals Engineering, 9(4), 449-464.

[4] Sarkar, G. G., Ghose, S., Chaudhuri, S. G., Sakha, S., \& Daschowdhury, K. P. (1984). Selectivity of coal macerals during flotation and oil agglomeration: a case study. Coal Perparation, 1(1), 39-52.

[5] Shu, X., Wang, Z., \& Xu, J. (2002). Separation and preparation of macerals in Shenfu coals by flotation. Fuel, 81(4), 495-501.

[6] Tempelmeyer, K. E., Crelling, J., Hippo, E., Paul, B., \& Yen, M. (1991). Coal refining by maceral liberation and separation. In annual international pittsburgh coal conference (pp. 329336). University of pittsburgh school of engineering centre for energy.
[7] Crelling, J. C. (1989). Separation and characterization of coal macerals: accomplishments and future possibilities. Prepr. Pap., Am. Chem. Soc., Div. Fuel Chem.; (United States), 34 (CONF-8904170-).

[8] Dyrkacz, Gary R., Carol AA Bloomquist, and Ljiljana Ruscic. "Chemical variations in coal macerals separated by density gradient centrifugation." Fuel 63, no. 8 (1984): 1166-1173.

[9] Jorjani, E., Esmaeili, S., \& Khorami, M. T. (2013). The effect of particle size on coal maceral group's separation using flotation. Fuel, 114, 10-15.

[10] Laskowski, J. S. (2001). Fine-coal utilization. Developments in Mineral Processing, 14, 307-351.

[11] Arnold, B. J., \& Aplan, F. F. (1989). The hydrophobicity of coal macerals. Fuel, 68(5), 651-658.

[12] Sahoo, S. K., Suresh, N., \& Varma, A. K. (2017). Kinetic studies on petrographic components of coal in batch flotation operation. International Journal of Coal Preparation and Utilization, 1-22.

[13] Hower, J. C., Kuehn, K. W., Parekh, B. K., \& Peters, W. J. (2000). Maceral and microlithotype beneficiation in column flotation at the powell mountain coal mayflower preparation plant, Lee County, Virginia. Fuel processing technology, 67(1), 23-33.

[14] Shu, X., Wang, Z., \& Xu, J. (2002). Separation and preparation of macerals in Shenfu coals by flotation. Fuel, 81(4), 495-501.

[15] Honaker, R. Q., Mohanty, M. K., \& Crelling, J. C. (1996). Coal maceral separation using column flotation. Minerals engineering, 9(4), 449-464.

[16] Jorjani, E., Hower, J. C., Chelgani, S. C., Shirazi, M. A., \& Mesroghli, S. (2008). Studies of relationship between petrography and elemental analysis with grindability for Kentucky coals. Fuel, 87(6), 707-713.

[17] Taylor, G. H., Teichmüller, M., Davis, A. C. F. K., Diessel, C. F. K., Littke, R., \& Robert, P. (1998). Organic petrology.

[18] ICCP, I. (2001). Handbook Coal Petr. suppl. to 2nd ed. ICCP. 1998. The new vitrinite classification (ICCP System 1994). Fuel, 77, 349-358.

[19] For Coal, I. C. (1998). The new vitrinite classification (ICCP System 1994). Fuel, 77(5), 349-358. 